\title{
The Differing Revolutionary Positions of Gramsci and Trotsky in Relation to Classical Marxism, the Peasantry, and the Majority World
}

\author{
James J. Brittain Acadia University
}

\begin{abstract}
Résumé
Malgré l'existence d'arguments différents au sein de la discipline, les théories de révolution marxiste ont un commun dénominateur principal : que la lutte des classes organisée peut amener en conséquence une société plus équitable qui prime le mode de production capitaliste. En élargissant le travail de Marx sur l'évolution des réalités du système de concurrence capitaliste, Lénine a souligné que, dans son expansion, le capitalisme tendait à devenir non pas un modèle de producteurs capitalistes concurrents mais de monopoles économiques centralisés au sein d'une société mondiale. En réponse à ce glissement d'économie politique du capitalisme mondial, Gramsci et Trotsky ont élaboré des théories différentes quant à l'importance des tactiques révolutionnaires dans une ère d'impérialisme. C'est dans cette tradition que le présent article explore les diverses réactions de révolution permanente et de guerre de position ou de manœuvre, tout en illustrant quelle théorie montre le mieux la capacité et les efforts d'émancipation de peuples vivant dans des pays hors des nations impériales (c.-à-d. de la majorité du monde).
\end{abstract}

\begin{abstract}
While differing arguments are found within the discipline, the principal denominator uniting theories of Marxist revolution is that organized class-based struggle can consequentially result in a more equitable society, one which surpasses a capitalist mode of production. Augmenting Marx's work on the growing realities of the competitive capitalist system, Lenin highlighted that as capitalism expands it increasingly becomes a model not of competing capitalist producers but one of centralized economic monopolies within global society. With this political economic shift in global capitalism, Gramsci and Trotsky penned differing theoretical responses toward the importance of revolutionary tactics in an age of imperialism. It is in this vein that this article delves into the varied responses of permanent revolution and war of position/manoeuvre, while illustrating which theory most effectively demonstrates the capacity and emancipatory efforts of peoples located in countries outside of the imperial nations (i.e. the majority world).
\end{abstract}




\section{The Differing Revolutionary Positions of Gramsci and Trotsky in Relation to Classical Marxism, the Peasantry, and the Majority World}

\section{Introduction: An Examination of Trotsky and Gramsci in Relation to the Majority World}

The subject of Marxist revolution has filled the coffers and walls of the academy for decades, be it through arguments of tactics, praxis, factionalism, or the advancement of the namesake's theoretical positions toward the implementation of more equitable social relations outside the capitalist mode of production. The proceeding seeks to engulf itself in the many varieties of Marxist debate by engaging in the theoretical positioning of Trotsky and Gramsci and their differing reflections of revolution with respect to the majority world. ${ }^{1}$ When discussing the majority world one of the most important factors of contention is one's response to the clear shift of the global political economy from the competitive capitalist world Marx lived in to one of imperialism. During the late $19^{\text {th }}$ and early $20^{\text {th }}$ century, Lenin $(1964 \mathrm{e} ; 1968)$ clarified that capitalism was increasingly altered from a model of competing capitalist producers to a centralized economic global reality of monopolies and cartels bringing forth not only a new stage of inequitable class relations but "the eve of the socialist revolution" (1964e: 187). Within this political economic shift in global capitalism, Gramsci and Trotsky penned dissimilar theoretical perspectives toward the importance of revolutionary tactics and formation. It is in this vein that this article delves into the varied responses of permanent revolution and war of position/manoeuvre, weighing which theory most effectively highlights the potential emancipatory capabilities of those within the majority world.

\section{Marx's Principle View of Capitalism as a (Global) Linear Process and Latter Thoughts on Developmental Leaps in Rural Societies}

With few exceptions, Marx and Engels demonstrated throughout their revolutionary careers that all nations, be them pre-capitalist or not, eventually become capitalist regions by the very necessity of capitalism's expansion in the pursuit of capital:

The need of a constantly expanding market for its products chases the bourgeoisie over the whole surface of the globe. It must nestle everywhere, settle everywhere, establish connexions everywhere. The bourgeoisie has through its exploitation of the work market given a cosmopolitan character to production and consumption in every country. To the great chagrin of Reactionists, it has drawn from under the feet of industry the national ground on which it stood. All old-established national industries have been destroyed or are daily being destroyed. They are dislodged by new industries, whose introduction becomes a life and death question for all civilized nations, by industries that no longer work up indigenous raw material, but raw material drawn from the remotest zones; industries whose products are consumed, not only at home, but in every quarter of the globe. In place of old wants,

1 Much like Ronaldo Munck's (1984) position toward geopolitical and global economic national terminology, the term 'majority world' is merely used as a definition for those many countries that exist as capitalist nations but are not included into the same power-centred framework as imperial nations (i.e. the minority world). 
satisfied by the productions of the country, we find new wants, requiring for their satisfaction the products of distant lands and climes. In place of the old local and national seclusion and self-sufficiency, we have intercourse in every direction, universal inter-dependence of nations. And as in material, so also in intellectual production. The intellectual creations of individual nations become common property. National one-sidedness and narrow-mindedness become more and more impossible, and from the numerous national and local literatures, there arises a world literature. The bourgeoisie, by the rapid improvement of all instruments of production, by the immensely facilitated means of communication, draws all, even the most barbarian, nations into civilization. The cheap prices of its commodities are the heavy artillery with which it batters down all Chinese walls, with which it forces the barbarians' intensely obstinate hatred of foreigners to capitulate. It compels all nations, on pain of extinction, to adopt the bourgeois mode of production; it compels them to introduce what it calls civilization into their midst, i.e., to become bourgeois themselves. In one word, it creates a world after its own image (1976: 487-488).

While foreshadowing the work of Lenin, Marx and Engels (1976: 488-489) argued that "independent, or but loosely connected provinces with separate interests, laws, governments and systems of taxation, became lumped together into one nation, with one government, one code of laws, one national class-interest, one frontier and one-customstarriff". Not dismissing that an imperial centre exists, they foresaw a world consolidated under the unilateral common denominator of fully developed capitalist conditions, in which all nations are to equally subscribe in full.

Intrinsically, it is not a question of the higher or lower degree of development of the social antagonisms that result from the natural laws of capitalist production. It is a question of these laws themselves, of these tendencies working with iron necessity toward inevitable results. The country that is more developed industrially only shows, to the less developed, the image of its own future (Marx, 1996a: 9).

One can recognize that an increasingly linear presentation of capitalist development prevailed within Marx's work, which argued that until capitalism is fully realized, both subjectively and materially, a new social paradigm cannot be realized; a "state of things which as yet exists only exceptionally on our earth" (Marx, 1996b: 518).

No social formation is ever destroyed before all the productive forces for which it is sufficient have been developed, and new superior relations of production never replace older ones before the material conditions for their existence have matured within the framework of the old society. Mankind thus inevitably sets itself only such tasks as it is able to solve, since closer examination will always show that the problem itself arises only when the material conditions for its solution are already 


\section{The Differing Revolutionary Positions of Gramsci and Trotsky in Relation to Classical Marxism, the Peasantry, and the Majority World}

present or at least in the course of formation. In broad outline, the Asiatic, ancient, feudal and modern bourgeois modes of production may be designated as epochs marking progress in the economic development of society. The bourgeois relations of production are the last antagonistic form of the social process of productionantagonistic not in the sense of individual antagonism but of an antagonism that emanates from the individuals' social conditions of existence-but the productive forces developing within bourgeois society create also the material conditions for a solution of this antagonism. The prehistory of human society accordingly closes with the social formation (Marx, 1987: 263-264).

Interestingly, in the last five years of his life, Marx had begun what can only be described as an in depth journey of intense re-examination toward his previous theoretical conclusions. One area where Marx journeyed was an examination of whether rural-based communal societies held the capacity to transform their conditions without realizing the confines of private property relations, essentially leaping-over a transitory stage of capitalist development. Such studies greatly expanded upon Marx's preceding work - which narrowly depicted the historic certainty of the capitalist process as realized solely within the most advanced countries of Western Europe ${ }^{2}$ - as they were incomplete.

In 1881, Marx (1992) wrote a letter to Vera Zasulich that explained how, in Western Europe, a transition of primitive accumulation took place where private property, through one's own labour, was violently altered to a system where capitalist private property, based on the foundation of exploiting another's labour-power through wage labour, came into being. ${ }^{3}$ In the communication, however, Marx proceeded to state that a process by which communal property could be transformed into private property may be, in fact, plausible (Marx, 1989c; 1992). Prior to this formal proclamation, Marx penned three separate drafts of said letter which saw him expand upon statements expressed in the latter pages of Capital, Volume 1. The purpose of such activity was to examine how Russia, unlike the West, where privately owned-lands were aggressively usurped from the rural populations, was able to make a transition that never experienced formal private ownership over rural lands (Marx, 1989b). In one draft, Marx stated that

in Russia, thanks to a unique combination of circumstances, the rural commune, still established on a nationwide scale, may gradually detach itself from its primitive features and develop directly as an element of collective production on a nationwide scale. It is precisely thanks to its contemporaneity with capitalist production that it may appropriate the latter's positive acquisitions without experiencing all its frightful misfortunes (1989b: 349).

In the same document, Marx (1989b: 353) asserted that the transition in Russia was not

2 See Marx (1996b: Part VIII).

3 See also Marx (1996b). 


\section{The Differing Revolutionary Positions of Gramsci and Trotsky in Relation to Classical Marxism, the Peasantry, and the Majority World}

"forced to pass through a long incubation period in the engineering industry, as was the West, in order to arrive at the machines, the steam engines, the railways etc". On the contrary, Russia "managed to introduce to their own country in the twinkling of an eye the entire mechanism of exchange (banks, joint-stock companies, etc.), which it took the West centuries to devise."

Further legitimacy to the above prospect is realized when hints of this thought were expressed a few years earlier. In 1877, Marx (1989a: 201) noted that as events within the capitalist process were "strikingly analogous" they nonetheless occurred "in different historical milieux", which led to "quite disparate results." From this, Marx clearly expressed that differences existed between time and region; therefore relations to development are to be extraneously different. Based on this position, Marx stated that it is imperative that one not manipulate

my historical sketch of the genesis of capitalism in Western Europe into a historicalphilosophical theory of general development, imposed by fate on all peoples, whatever the historical circumstances in which they are placed, in order to eventually attain this economic formation which, with a tremendous leap of productive forces of social labour, assures the integral development of every individual producer (1989a: 200).

While Marx (1996a) clearly expressed that the most developed countries illustrate the image of the less developed nations' future, he stated that this did not mean that "in all circumstances the development" followed the same path (1989b: 352). Paul Le Blanc (1996: 30) has also supported this claim by citing that Marx did not believe that "because primitive communal societies had been obliterated in the Western capitalist countries, all remaining forms of communal society in the world are doomed to extinction". ${ }^{5}$ Hence, differing methodologies and adaptations to capitalist development will and must be realized between parts of the world, based on the contrary sectors' historical development, while they all nevertheless come to a place of shared capitalist evolution. ${ }^{6}$

In the late- $19^{\text {th }}$ century, as Russia's socioeconomic status rapidly moved, Marx and Engel went so far as to contemplate, a year after Marx had sent Zasulich the official letter, whether "a form of primeval common ownership of land, even if greatly undermined" could "pass directly to the higher form of communist common ownership?" Stemming

4 See also Marx and Engels (1976: 505).

5 The said position was also supported by Lenin (1964a), who felt that pre-capitalist and peasantbased collectives could act as a benefit for capitalist industry in some regions of the world.

6 This point is clearly realized in the contemporary period where the advancement of capitalism has never been so broadly executed within the global economy. Nevertheless, the fact remains that over three billion people of the world live in agricultural and peasant-based societal and economic conditions (Amin, 2004). 
from this question, Marx and Engels projected, through an internationalist position, that "if the Russian Revolution becomes the signal for a proletarian revolution in the West, so that the two compliment each other, the present Russian common ownership of land may serve as the starting point for communist development" (Marx and Engels, 1989: 426). The preceding clearly illustrates Marx and Engels' acceptance and belief, albeit in the latter years of Marx's life, that under certain historical and material conditions specific societies, could arise from a rural-based model of communal ownership to one of socialized property relations.

\section{Trotsky's Permanent Revolution and its Practical Relation to the Majority World}

Like a key to a lock, the argument of uneven and combined development lends itself to the theory of permanent revolution. Countries must come to a place of formal sociopolitical structure, bourgeois models of democratic policy, and development - albeit through each country's contextual conditions as related to the global economy. While some countries embody a historic classical approach to their structured relation to capitalist development others must come to a place of making leaps, which allow certain backward nations to transcend the socioeconomic model(s), as noted in Marx's linear stages of economic evolution. The reasoning behind countries that engage in a classical linear model and those that leap are based on the dynamics of the increasingly expansionary needs of the world economy, factors that continue to have economic power centralized in the hands of a specific few and the nations which they inhabit, while other peoples and their national environments, both politically and economically, remain sanctioned by external forces of capitalism. $^{7}$

Based on this growing need for capitalism to satisfy its directors internal wants via the continued quest for increased capital, the bourgeoisie of the advanced capitalist countries with the backing of the State in which they are socio-geographically positioned, have politically and economically entered into a globalized model of capitalism that exists outside of the already fully developed capitalist regions and probes the peripheries ensuring fiscal return and natural resource accessibility. From this capitalist intrusion comes a unique conjunction of methods that accelerate the capitalist process within the majority world countries coupled by a blending of the more domestically traditional methodologies of production. Trotsky (1936: 5-6) acknowledged this geo-economic dynamic by describing how, "under the whip of external necessity," certain nations within the majority world

7 In addition to the above, it is worth noting, from a sociological perspective, that Trotsky's theory of uneven and combined development evoked an interesting recognition of not only the macrolevel nuances associated to capitalist development but also those of micro-level realizations, which pervade society on a more conducive localized front. Trotsky (1969) stated that workers must not be uneven or fractured in their consciousness of class society but must come to a common or combined understanding of how societal ills; racism, gender-based discrimination, sexual aggression, are in actuality sub-categorical aspects associated to, and permeated through, the capitalist induced social relations of production. Upon the rise of class consciousness and the awareness of these uneven social factors, a combined understanding of the revolutionary objective is achieved. 
Classical Marxism, the Peasantry, and the Majority Worid

would be "compelled to make leaps ... drawing together ... the different stages of the journey, a combining of separate steps, an amalgam of archaic with more contemporary forms." ${ }^{\prime 8}$ Such a position clearly augmented Lenin's thesis that capitalism, even at its most advanced stage, ensures and prolongs the most beneficial aspects of 'archaic' modes of production within the sectors of the majority world.

In similarity with Trotsky's claim of an amalgam of productive forms coming together, Lenin (1964a: 120) wrote that "large-scale production in agriculture is superior to small production only up to a certain limit." What Lenin meant by this phrase is that benefits can be recognized in the clear and focused production of specific crops, which profit from more localized small-scale farming rather than large-scale production (i.e. grapes, strawberries, and cocoa). However, small production also held a much more qualitative benefit to the capitalist producer in relation to the level of exploitation that could be pressured on the rural small-producer and their family in the context of production. Interestingly, Lenin illustrated that the peasant or small farmer (archaic form) conducted far more work than a purely wage-labour-based worker (contemporary form), for the peasant did not merely employ their labour-power in the fields but systemically continued to work even after the fields have been cared for:

[The] peasant also works in the household, works on building and repairing his hut, his cowshed, his implements, etc., "not counting" all his additional work, for which a wage-labourer on a big-farm would demand payment at the usual rate. It is not clear to every unprejudiced person that overwork has incomparably wider limits for the peasants-for the small farmer-than for the small industrial producer (1964a: 129)

Disturbingly, Lenin, echoing Kautsky's early work, argued that maintaining small production methods, within specific contexts and regions, actually results in a maximized benefit for the contemporary capitalist owner. This need not be solely on the basis of the 'overwork' thesis but also on the exploitive progression of the rural family structure as well.

Lenin provided an unarguable expression of how a peasant cultivator utilized family labour (employing disparities toward conventional Western interpretations of gender and child rights) within the production process. If a capitalist could encourage peasant-based small-scale production, which utilized child labour, they had the ability to increase their fiscal return for it required less to sustain a child than an adult. Through comparing levels of consumption it was more profitable for the urban-based rural-landowner to continue small-scale peasant production in certain respects because liability payments for the labourers were, in reality, smaller than in relation to large-farms with full-scale adult work forces. The above provides an empirical example of Trotsky's theory of contextual leaps

8 See also Trotsky (1969: 152). 


\section{The Differing Revolutionary Positions of Gramsci and Trotsky in Relation to Classical Marxism, the Peasantry, and the Majority World}

as they occur in a majority world setting where 'contemporary and archaic forms' are combined so as to derive a consistent influx of profit rates for the dominant class within the domestic and global class structure.

As noted in his famous three distinguishing points that construct the theory of permanent revolution, Trotsky illustrated that one of the essential elements of the socialist revolution was the need for a bourgeois-democratic societal structure to be erected. Such a model proceeded to create an effective environment in which the proletariat increasingly became educated through their growing social-relation to the means of production compounded by the necessity for a socialized sociopolitical milieu. In addition to this, Trotsky aimed his theory towards those countries that held the 'whips' as the target of change. Stating that backward countries, and the bourgeoisie therein, were incredibly weak and at the directional mercy of the advanced country's bourgeoisie, Trotsky (1969) logically deduced that only the most advanced nations could make victorious revolution - subsequently relieving the most concentrated capitalistic pressures from the world economy. This is not to say that revolutionary movements would not be of necessity or importance within the majority world, according to Trotsky. Rather he would argue that they could not be, in and of themselves, victorious based on the fact that socialist transformation could only come to fruition through a unified global model with the proletariat of the most advanced leading the (final) charge.

Again such a position raises similarities with notions found within classical Marxist theory. Marx took the position that clearly saw revolution as being victorious only through internationalist methodologies:

Citizens, let us bare in mind this fundamental principle of the International: solidarity! It is establishing this life-giving principle on a reliable base among all the workers in all countries that we shall achieve the great aim which we pursue. The revolution must display solidarity, and we find a great example of this in the Paris Commune, which fell because there did not appear in all centres, in Berlin, Madrid, etc., a great revolutionary movement corresponding to this supreme uprising of the Paris proletariat (1988: 256).

From this, one could understand how Trotsky (1969) and Marx (1987) believed that until the global conditions for capital have been set in place through permanent revolution the transition to socialism is doomed to fail.

The proper task of the bourgeois society is the creation of the world market, at least in outline, and of the production based on that market. Since the world is round, the colonization of California and Australia and the opening up of China and Japan 
Classical Marxism, the Peasantry, and the Majority Worid

would seem to have completed this process. For us, the difficult question is this: on the Continent revolution is imminent and will, moreover, instantly assume a socialist character. Will it not necessarily be crushed in this corner of the earth since the movement of bourgeois society is still in the ascendant over a far greater area? (Marx, 1983: 347)

In specific relation to the majority world, Trotsky devised a practical-theoretical and empirically practical description of how principle methods of revolutionary social change might come into being within backward countries. Due to the alternative relation that backward countries had to the world economy, unlike those of say advanced capitalist countries within Western Europe, Trotsky argued that these peripheries could implement democratic tasks but not through the classical stages, where the dictatorship of the proletariat came into being as a result of the bourgeois-democratic revolution (as depicted by Marx). Rather a more immediate transformation would be plausible through an immediate revolutionary dictatorship of the proletariat procuring democracy in unison with its materialization as a societal force. One may even see this method of democratic development as putting aspects of Marx's classical stages on their head where the dictatorship of the proletariat does not result after an extended period of bourgeois democracy but rather "the road to democracy passed through the dictatorship of the proletariat" (Trotsky, 1969: 132).

Such achievements could only come into being through the importance and necessity of national revolutionary positioning being the preliminary platform from which socialist revolution materialized. However, Trotsky (1969) took note that the important struggles of the backward countries were only a contextual link, a provisional process, a categorical characteristic of permanent revolution due to the practical and theoretical realities of the world economy. Trotsky clearly held a position that while international revolution was the only pathway through which socialism could pass; it was solely the proletariat within the most advanced capitalist countries that had the capacity to lead the way.

Trotsky's theoretical (and practical) position was firmly grounded in the realistic assessment of capitalism's construction within the global economy. Though emerged in numerous popular revolts and revolutionary attempts throughout the 1900s, backward countries remained within the framework of imperialism and continue to exist within a limited and restricted capitalist environment of archaic and contemporary forms. Their domestic bourgeoisie, while having internal power and a connection to the world economy, did not hold a firm grasp of the centralized power that was located within the most advanced countries. While important, the vast majority of the upheavals of the $20^{\text {th }}$ century were orchestrated, designed, and conducted through minority populations of intellectuals and professionals, fragments of the religiosity, small-fractured military collectives or 
associated populists, limited bureaucracies, and most of all peasants. Trotsky would not dismiss these significant attempts at change but rather characterized such methods as failing to reflect and/or being unable to affect the necessity or goal of the proletarian (worker) revolution. Hence, Trotsky would dogmatize the dictate of Lenin (1964c: 28) that stated it was the workers, in and of themselves, that must create emancipatory conditions through the implementation of socialist revolution. As a result of this, Trotsky would applaud the revolutionary movements of the backward countries as slight actors in the permanent revolution, not leaders.

Trotsky acknowledged both the good and telling reality of the revolutionary attempts throughout the backward countries of the majority world. As he proclaimed in Results and Prospects, revolutions within backward countries were incredibly important in that they had the capacity to "infect the Western proletariat with a revolutionary idealism" (1969: 115). Nevertheless, Trotsky believed that the true socialist revolution cannot theoretically, practically, or logically be centralized or isolated within a land of peasants or semi-industrial forms but must proceed in the land of industrialized proletarians. He clearly noted that socialist transformation "lies only in the victory of the proletarians of the advanced countries," for it was from their lands that the most powerful capitalists control the world's economic scales (1969: 133).

To Trotsky, simple logic suggested that it is the proletariat from the most advanced countries that could procure international revolution, alongside the combined nationallylinked revolutionary struggles of the backward countries within the majority world. It was in the former that the domineering interests and economic power of the bourgeoisie control the cracking of the global capitalist whip; therefore, it was the workers of these nations that were to lead the permanent revolution through usurping the whip and stopping it from striking the workers of the world. In relation to the majority world then, Trotsky applauded the activity and revolutionary organizing of the masses; all-be-them sanctioned to a subservient position to that of the advanced capitalist countries' proletarian body, which must initiate and front the permanent revolution.

\section{Gramsci's War of Position - War of Manoeuvre and its Practical Relation to the Majority World}

Gramsci developed a specific two-pronged approach toward revolutionary tactics dependent on the homogenized or formalized distinctive, yet related, forms of civil society and political society. Gramsci (1971) argued that numerous backward countries had a centralized and unified political and civil society, where little differentiation was realized between the two. Under these certain conditions, a direct frontal assault or war of manoeuvre could be an accurate method by which the revolutionary body would 


\section{The Differing Revolutionary Positions of Gramsci and Trotsky in Relation to Classical Marxism, the Peasantry, and the Majority World}

demobilize the dominant class structure for it was so strongly concentrated within one principle character or body; the State. Within more advanced capitalist countries, which had a clearly developed civil society, external (but related) to the political society, Gramsci argued a more focused war of position was of necessity. ${ }^{9}$

A war of manoeuvre provided an outright transgression against the State resulting in the subsequent taking of the concentrated power via coercive and economic factors, hence it was through this process that revolutionaries were able to demobilize "all the resources of the state's hegemony" (Gramsci, 1971: 239). Contrary to the war of manoeuvre, applicable to the backward countries, the advanced capitalist centres, where private capitalists existed external to the State, had the capacity to utilize civil society during times of political instability. Gramsci (1971: 238) noted that "when the state trembled a sturdy structure of civil society was at once revealed". For example, if the State was threatened or deconstructed by revolutionary forces then segments of civil society had the private capacity to employ reactionary forces external to the coercive arm of State thus entering into a counter-revolutionary conflict assisting the continuity of the capitalist paradigm. In short, within the advanced countries the flagging State was able to be held up by the bourgeois capitalist element (Gramsci, 1971; 1978).

To Gramsci (1971), based on the conditions he witnessed in the early 1900s coupled by the rise of fascist Italy, which could be argued by some as a backward country in contextual relation to Britain, France, or Germany, a war of position must equally unify the proletariat and the peasantry in ideological position and democratic movement. Unlike France or Britain, Gramsci stated that Italy held a different class dynamic and therefore methods of procuring state power were to be different. Within Some Aspects of the Southern Question, Gramsci (2000b: 30-31) stated, when referring to the Turin Communists (just prior to the formalized construction as the Partito Comunista d'Italia (PCdI) in 1921), that the revolutionary working-class

posed to themselves concisely the question of the "hegemony of the proletariat", in other words, of the social basis of the proletarian dictatorship and the Workers' State. The proletariat can become the leading and ruling class to the extent to which

9 Unlike Russia, which was not only fragile but had little deviation between the State (political society) and Civil society (private), the most advanced capitalist Western countries were thoroughly entrenched in a societal correspondence that allowed the continuity of its functions to persist even if one aspect of the bilateral relation was harmed (Gramsci, 1971). In light of this, certain countries would move from a 'war of position' to a 'war of manoeuvre', thus organizing the capabilities for a cultural shift in society in combination with a frontal assault of the conventional politico-economic structures. Russia was able to implement a direct assault on the State, via war of manoeuvre due to a centralization of political-economic factors, thus lacking diversified power. However, in advanced countries that utilize a strong corresponding relation of civil society and the political structure, war of position in needed. This is evident to Gramsci based on the fact that during times of strife civil society can be swayed, i.e. fascist Italy and therefore the implementation of hegemony must be countered (Gramsci, 1971). See also Lenin (1964f). 
it succeeds in creating a system of class alliances which enables it to mobilize the majority of the working populations against capitalism and the bourgeois State; this means, in Italy, in the actual relations existing in Italy, to the extent to which it succeeds in obtaining the consent of the large peasant masses..

From this, one clearly recognizes that Gramsci greatly contextualized national conditions and saw that they must be carefully understood in order to gauge avenues to procure political extension via class alliances.

Interestingly, Gramsci offered a less cited subcategory within the war of manoeuvre scenario when he explained that when fragility of political society reveals itself, emancipatory revolutionaries may wish to employ underground warfare and commando tactics to respond to the enormity of wealth and power that reactionary forces sanctioned through the payroll of civil society. Linked to war of manoeuvre, these "forms of struggle are specific to weak, but restive, minorities confronted by well-organized majorities" (1971: 231). One recognizes the similarities between Gramsci's discussion and Marx and Engels call for such a strategy where an unequal politico-military setting existed.

A nation that wants to conquer its independence cannot restrict itself to the ordinary methods of warfare. Mass uprising, revolutionary war, guerilla detachments everywhere-that is the only means by which a small nation can overcome a large one, by which a less strong army can be put in a position to resist a stronger and better organised one (Marx and Engels, 1977: 171).

Consistent with his Marxist-Leninist promotion of the importance of the Party ${ }^{10}$, Gramsci (1971) stated that while such methods of unconventional warfare were beneficial they alone could not embark, nor affect, revolutionary change in and of themselves, for it was only through the realm of politics, vis-à-vis the Party, that change and consciousness materializes. ${ }^{11}$

For Gramsci, change is different and dependent on the contextual conditions of class struggle and composition as realized within any given national sociopolitical environment. From this position and through his own experience in Italy, Gramsci noted the importance, as did Lenin (1964d; 1964f), of class alliances, particularly between the proletariat and peasantry (Gramsci, 1995; 2000b). Adding to this scenario, Gramsci pointed to the need of a war of position to mobilize and consolidate support and allies in the pursuit of socialism. Not only did Gramsci $(1971 ; 1978 ; 1995)$ call on the need for a new realm of thinking, a national-popular collective will, but so too did he address the need to align and organize

10 Gramsci was not only a founding member of the Partito Comunista d'Italia (PCdI) but was elected to the Central Committee in 1921 and by 1926, just prior to his arrest, had become the General Secretary of the Party (Gramsci, 1957).

11 See also Lenin (1965d). 


\title{
The Differing Revolutionary Positions of Gramsci and Trotsky in Relation to Classical Marxism, the Peasantry, and the Majority World
}

the subaltern in a unified collective of antagonism to capitalist tendencies. ${ }^{12}$ Here one can recognize a concrete difference between Gramsci's 'united front' model and Trotsky's workerist promotions, a position that is incredibly important in a global dynamic where "the agricultural and peasant world still makes up at least one-half of humanity" (Amin, 2004: 32).

Gramsci differed greatly from Trotsky in that he placed a significant importance on the differing internal class conditions of national contexts. This was emphasized by Gramsci when he called for alliances to be erected through a war of position due to the fact that not all countries could (or would) follow a European strategy, a position that was clearly supported by Lenin (1964b). Therefore, he put forth a deeply national perspective that would differ from country to country based on national conditions, a strategy that still holds relevance in the capacity for countries to come together to form an international socialist struggle.

\begin{abstract}
[A]ccording to the philosophy of praxis (as it manifests itself politically)-whether as formulated by its founder [Marx] or particularly as restated by its most recent great theoretician [Lenin]-the international situation should be considered in its national aspect. In reality, the internal relations of any nation are the result of a combination which is "original" and (in a certain sense) unique: these relations must be understood and conceived in their originality and uniqueness if one wishes to dominate them and direct them. To be sure, the line of development is towards internationalism, but the point of departure is "national"-and it is from this point of departure that one must begin (Gramsci, 1971: 240)
\end{abstract}

While Gramsci placed a deep relevance on national class dynamics and alliances, it is important to note that he fully acknowledged the necessity for internationalist revolution. In 1919, Gramsci stated that socialism can only be "resolved within a world context" based on the fact that

capitalism is a world historical phenomenon, and its uneven development means that individual nations cannot be at the same level of economic development at the same time. In the international sphere, competition, the struggle to acquire private and national property, creates the same hierarchies and system of slavery as in the national sphere; and further, competition is eliminated in favour of monopoly far more efficiently in the international than in the national sphere (1977: 69).

As one can recognize, Gramsci is not supporting a Stalinist position of 'socialism in one country' but rather elaborating on the stated position of recognizing the importance of the

12 Gramsci took a position similar to that of Lenin (1964f: 46-47) which stated "we have always known and repeatedly pointed out that the bourgeoisie maintains itself in power not only by force but also by virtue of the lack of class-consciousness and organization, the routinism and downtrodden state of the masses"; therefore, an increased class-conscious population must be erected. 
'national' within the 'internationalist' formula, as expressed by Lenin. ${ }^{13}$

Uneven economic and political development is an absolute law of capitalism. Hence, the victory of socialism is possible first in several or even in one capitalist country alone. After expropriating the capitalist and expropriating the capitalists and organizing their own socialist production, the victorious proletariat of that country will arise against the rest of the world-the capitalist world-attracting to its cause the oppressed classes of other countries, stirring uprisings in those countries against the capitalists, and in case of need using even armed force against the exploiting classes and their states. The political form if a society wherein the proletariat is victorious in overthrowing the bourgeoisie will be a democratic republic, which will more and more concentrate the forces of the proletariat of a given nation or nations, in the struggle against states that have not yet gone over to socialism. The abolition of classes is impossible without a dictatorship of the oppressed class, of the proletariat. A free union of nations in socialism is impossible without more or less prolonged and stubborn struggle of the socialist republics against the backward states (Lenin, 1966a: 342).

Viewing the world through a Leninist perspective via national conditions of historical development and revolutionary positioning, Gramsci extended that the diverse and important historical relations of national contexts meant differing strategies of revolutionary positioning were to be employed in accordance to the domestic social relations of production. This brought Gramsci to an identification of the socioeconomic and political realities of the West and how such conditions played out differently in the context of the Russian revolution. ${ }^{14}$ In the shadow of Lenin, Marx and Engels, Gramsci (1971) supported the notion that socialist revolution began on the national stage, from where it could evolve to a larger collective global stage as other national class-struggles did the same in their perspective contexts. From this, one can appreciate that Gramsci shelved Trotsky's doctrine as a disregard of the need to unify non-bourgeoisie sectors of the population and that the theory placed a dogmatic all encompassing application of aggressively offensive revolutionary tactics without regard for the various national circumstances prevailing throughout the world. Instead of adopting a 'Western' elitist and homogenous strategy, which suppressed the peasantry, Gramsci (2000a) realistically argued for the proletariat in specific countries to work alongside peasants as suggested by Lenin (1964d; 1964f). ${ }^{15}$ In keeping with such a position, Gramsci fully supported and

13 Le Blanc (1996) cites Gramsci as being a dissident and maverick thinker of Marxism within the context of the 1920s, when Communism was witnessing a significant de-radicalization in some regions of the world with others subscribing to increasingly dictatorial Stalinist interpretations. If not for prison, and therefore largely silenced from the international sphere, some authors have argued that Gramsci's resistance to the Comintern would have likely resulted in his expulsion or break from the PCdI and subsequently the Third International (Spriano, 1979; Fiori, 1971).

14 See Marx (1989a).

15 See also Trapeznikov (1981) and Rochester (1942). 


\section{The Differing Revolutionary Positions of Gramsci and Trotsky in Relation to Classical Marxism, the Peasantry, and the Majority World}

followed Lenin's position of a "revolution-democratic dictatorship of the proletariat and peasantry" (Lenin, 1965c: 141) ${ }^{16}$, while denouncing Trotsky's permanent revolution. ${ }^{17}$

Within his famous Lyons Theses, Gramsci (1978) argued quite effectively that at the base of any national economy of a majority world country lay not only the integral infrastructure that provided subsistence-based continuity for the domestic collective but so too did it envelope an essential cornerstone to the industrial sphere. The agricultural sphere is essential in the fact that both urban and rural consumption is largely dependent on the sustainability of the rural sphere of food production and/or utilization of raw material and natural resources. Therefore, a disruption within this essential aspect of production causes a fracturing of both the industrial, and subsequently those imperial countries attached to the majority world. ${ }^{18}$ Gramsci claimed that unlike the most advanced capitalist countries the dominant members of the ruling class within backward countries were not merely urban-based property-owners but rather a comprised cohesion of individual interests and agreements between large land-owners, petty-bourgeoisie, and the industrial bourgeoisie. Within these compromises, argued Gramsci, lay weaknesses of heterogeneity through the country's social structure; hence, the aptitude for proletarians to induce revolutionary wedges, thus expanding fragmentations within the State and civil society. Unlike the diversity of the domestic ruling class, the proletarian base within the majority world countries has the potential to increasingly unite under the reality of economic exploitation and political suppression, thus leaving little avenue for the adoption of social-democratic reforms or opportunism. Increasingly, reactionism is the methodology realized against both the rural and urban labourers consequently increasing the revolutionary positioning of the most exploited peoples.

Like Lenin (1964a), Gramsci highlighted the extensive stratification of the rural population, far from that described by some who see the bucolic body as a homogenous collective of petty-bourgeoisie property-holders or individuated self-interested labourers. Contrary to this view, Gramsci documented, as had Marx at times ${ }^{19}$, that a certain strata

16 See Gramsci (1971; 2000a).

17 Gramsci thoroughly denounced Trotsky's doctrinaire standpoint of forcing, by pull or by push, a method of rural industrialization on the Russian peasantry, a position that was all too ironically adopted by Stalin (Fiori, 1971).

18 See also Marx (1996b).

19 Within Class Struggles in France, Marx (1978: 122) argued that although the peasantry was exploited, albeit in a different fashion from the industrial proletariat, they were still exploited in the same "form" - that form being "capital". In the third volume of Capital, Marx and Engels again expressed this point by stating that what happened within the rural stage of economics and that which was apparent in the urban setting were the same. Both were affected by capitalism, as both were producers, although their exploitation was in differing contextual circumstances. It was within this volume that Marx stated, "the farmer produces wheat, etc. in much the same way as the manufacturer produces yarn or machines" (Marx and Engels, 1998: 608). Marx (1996b: 386) clearly recognized and argued that "a radical change in the mode of production in one sphere of industry involves a 
within the rural sector, the poorest echelon (and largest), would, in ideology, theory, and practice, align itself with the proletariat - and its leadership - to represent its interests of emancipation. ${ }^{20}$

It is in the Lyon Theses that one recognizes Gramsci's clear deconstruction of any theory that announces the advanced countries as being the only (leading) regions in which revolution can successfully come into fruition. Based on the reality of internal socioeconomic weakness and/or political class fragmentation, due to proletarian-based action through Party organizing and not mere theoretical economism ${ }^{21}$, majority world countries have been shown throughout the $20^{\text {th }}$ and $21^{\text {st }}$ century as carrying the capacity to engage and win revolutionary struggles.

[T] he most favorable conditions for the proletarian revolution do not necessarily always occur in those countries where capitalism and industrialism have reached the highest level of development, but may instead arise where the fabric of the capitalist system offers least resistance, because of its structural weaknesses, to an attack by the revolutionary classes and its allies (Gramsci, 1978: 346).

\section{The Theoretical and Practical Contentions Leading Gramsci's Theory to Surpass Permanent Revolution}

While Gramsci and Trotsky came to a position of appreciating the importance of, and

similar change in another"; therefore, under capitalist formation the urban worker, as well as the rural labourer, were united in the constraint of the exploitative system. It is in this synchronized relation that both the peasant and the industrial worker shared a similar class disposition (Marx and Engels, 1976; Marx, 1989d). In this shared position, a radical alteration within the rural sphere would result in a dramatic effect within the urban; hence the relevance of rural action in equal accordance with urban conflicts.

20 This was in direct contention to Trotsky's take on the rural population, which he clearly saw as a homogenous mass. Another flaw within Trotsky's work was that he placed a great deal of weight on the subject of commodity prices being used as a wedge between the rural and urban workforce, ironically similar to Luxemburg's repressive accumulation thesis. While he rightfully promoted that capitalists (and governments) deny the ability to increase wages due to a false reality of costs and expenses - the "'excessive' demands of the workers" - Trotsky failed to understand that peasants, farmers, and small merchants within the countryside were increasingly leaving the bucolic regions of the country for the city; therefore, increasingly alleviating the 'wedge', as Marx clearly noted it would. While it is certainly true that the capitalist used a wedge between the working-class populations, the rural population leaving their organic habitat decreased the wedge described by Trotsky (Trotsky, 2000).

21 Trotsky (2000) tried to argue that mere economic and social crises would lead to numerous sectors of the population running to unify under the Fourth International, compounded by increased union membership. On the contrary, during social and economic crises the opposite has been documented; increased factionalism, growth of interest groups and individualized movements promoting issues other than anti-capitalism; individual apolitical acts of violence, de-certification of organized labour and membership decreases; etc. 


\section{The Differing Revolutionary Positions of Gramsci and Trotsky in Relation to Classical Marxism, the Peasantry, and the Majority World}

subsequently following, Lenin's guiding revolutionary praxis, both theorists' early interpretations of Marxism were ironically intentionally (Trotsky) or unintentionally (Gramsci) based on concepts that were, in fact, antithetical to the political strategies of Leninism. From an early stage, Lenin had acknowledged, through both theoretical and contextual investigation, the importance of a centralized and disciplined political framework and leadership under which the increasingly class-conscious revolutionary mass needed to mobilize (Lenin, 1964b; 1965a). Such a theory however, was far from adopted by either Gramsci or Trotsky prior to the spring of 1917.

One can recognize, rather clearly, that prior to 1921, Gramsci (1994), while supporting the achievements of Lenin in $1917^{22}$, held a critical view of the importance of Party formation and leadership in relation to the emancipation of the working-class. His early and still developing position not only disagreed with but contradicted Lenin's classical discussion of the necessity of a perceived top-down democratic centralized system. Early on, Gramsci (1977: 171) empirically believed workers, in and of themselves, to be the vehicles of change for he witnessed that it was the revolutionary Italian workers themselves who were not only leading the charge of proletarian interests and action but that they were doing so without any formal and revolutionary party structure:

There can be no workers' government until the working class is in a position to become, in its entirety, the executive power of the workers' State. The laws of the workers' State need to be executed by the workers themselves: only in this way will the workers' State avoid the danger of falling into the hands of adventurous and political intriguers, of becoming counterfeit of the bourgeois State. Hence the working class must train and teach itself and educate itself in the management of society. It must acquire the culture and psychology of a dominant class, acquire them through its own channels and its own system - meetings, congresses, discussions, mutual education. The Factory Councils have been an initial expression of these historical experiences on the part of the Italian working class as it moves towards self-government in a workers' State.

This contradiction however cannot be thought of as an intentional disagreement or dismissal of Lenin's work in What Is to Be Done (1964b) or One Step Forward, Two Steps Back (1965a) but rather a contextual realization within the political and economic realities in Italy at the time. One must remember that at this time, the party structure of the Italian Socialist Party (PSI) was dominated by a small select group who were increasingly seeking to satisfy mutual stability within Italian society via capitalists, trade union leaders, and the working-class. ${ }^{23}$ In support of Consolo's claim of the material contextual political

22 In April of 1917, Gramsci (2000a; 1977) had written letters of formal support to Lenin in regard to the Russian revolution.

23 As told to the author by Marco Consolo, Department Head of International Development for the Partito della Rifondazione Comunista (PRC) in Bogotá, Colombia (December 4, 2004). 
conditions of this period in Italy, Michael Löwy (2005: 178) noted that in

Italy, specifically, the proletarian masses showed much more initiative and fighting spirit than the leadership of the trade unions or the socialist party ... The Party leadership, dominated by "centrist" elements, lagged far behind the revolutionary level attained by the masses, to the point that, during the general strike in Turin, it refused to give its full support to the movement, which was sharply criticized as an "anarchist deviation".

At the time, Gramsci (1977: 176-177) perceptively documented that in light of such an un-committed leadership and praxis, it was in fact the workers who led the struggle with the Party formation acting as a simple tool of conventional political legitimacy, i.e. a mechanism of organization.

From this point of view, the problem of proletarian unity must engage the attention of all revolutionaries conscious of enormous difficulties the proletariat faces if it is to achieve its historical mission. The proletarian revolution demands clear, precise situations and well defined responsibilities: the working class needs to be placed in a position to make rapid and direct judgments. But syndicalism, in both its reformist and revolutionary guises, has given rise to political parties which are acknowledged and ambiguous. Small groups of individuals, who have placed themselves at the head of the working-class organization as organizational technicians, specialists in one method of struggle rather than another, have enslaved the masses to their particular political tendencies. The masses have been enslaved to clandestine programmes over which they have no control. It is the vested interests of these clandestine and closed groups, frequently of single individuals, that have always prevented the unity of the Italian proletariat from being realized in practice. Now the historical process of capitalism has created the conditions in which the masses themselves, using their own methods and direct action, can achieve unity. Proletarian unity forged by the workers themselves represents a higher stage of the unity which de facto exists: it is the stage in which the workers show that they have acquired a consciousness of their own unity and want to give it a concrete expression, a sanction.24

Until 1920, the most turbulent year of Italian proletarian activity where numerous workerled factory occupations and a major national general strike occurred, Gramsci supported the notion that workers could achieve self-emancipation through their own methods. While such a position can in no way be interpreted as a Leninist premise, Gramsci did not see this line of reasoning and action to be in oppositional defiance to the Lenin's philosophy of praxis. To the contrary, Gramsci (2000a) saw his position as being reflective of the 1917

24 As one easily recognizes, this method is quite different than Lenin's based on the fact that Gramsci argues for a 'from-below' method of procuring power, not a centralized democratic method. See Gramsci (1977). 
revolution and Lenin's own strategy of 'dual power'. Gramsci likened the increasing and growing class-conscious militancy of the Italian workers and peasantry as being quite similar to Lenin's own domestic circumstances prior to, and during, 1917. He perceived the growth and power of the revolutionary worker-controlled "factory councils to Lenin's theorization of the soviets" and therefore felt that his own position toward emancipation was in contextual reflection to Russia (Sacouman, 1999: 118).

Even more interesting was the fact that while his early theoretical writings and political activity criticized the Party formation and its limits within Italy, Gramsci (1977: 5354) simultaneously supported in full the Party dynamic within the Soviet Union and the efficiency in its advancement toward freedom through the democratic-centralism of Lenin's program.

A hierarchy is being constituted: from disorganized and suffering masses one moves up to the organized workers and peasants, then the Soviets, then the Bolshevik Party and finally one man: Lenin. It is a hierarchical gradation based on prestige and trust, which formed spontaneously and is maintained through free choice... Once this hierarchy has been formed, it develops its own logic. The Soviets and the Bolshevik Party are not closed organisms; they are continually being integrated with one another. It is in this that freedom holds sway, that freedom is guaranteed. They are not castes, but organisms in a continuous state of development. They represent the development of consciousness, represent the capacity of Russian society to become organized. All workers can take part in the Soviets, and all workers can exert their influence in modifying the Soviets and bringing them closer in line with what is wanted and needed. The direction being taken by Russian political life at the moment is tending to coincide with that taken by country's moral life, by the universal spirit of the Russian people. There is communal movement between the hierarchical levels: an uncultivated individual gets a chance to improve himself in the discussion over the election of his representative to the Soviet - he himself could be the representative. He controls the organs because he has hem constantly under review and near to hand in the community. He acquires a sense of social responsibility, and becomes a citizen who is active in deciding the destiny of his country. Power and awareness are passed on, through the agency of this hierarchy, from one person to many: society is such as has never before appeared in history.

From here, one acknowledges that Gramsci's perception toward the Party was not total or dogmatic but systemically based on the differing historical conditions of specific regions experiencing an increase in revolutionary emancipatory potential, a position that reflected Lenin's own belief, i.e. the national question. As noted through his early and later works, Gramsci fully supported the Leninist-based necessity of each country coming to recognize 
and engage in their own socialist development via their own historical and political context, for "the struggle of the proletariat with the bourgeoisie is at first a national struggle" where "the proletariat of each country must, or course, first of all settle matters with its own bourgeoisie" (Marx and Engels, 1976: 495). ${ }^{25}$ It is based on this premise that Gramsci

25 As noted, Trotsky contested that revolutionary attempts within backward countries were not effective due to the fact that the domestic bourgeoisie of the majority world were too weak in relation to capitalists in imperial centres. This was, and remains to be, incredibly problematic in the fact that Trotsky separated or categorized a hierarchical model of exploitation and differentiated bourgeois capitalists within imperialism. Within the Transitional Program, Trotsky (2000) dismissed the theoretical and empirical writings of Marx and Engels in that he argued differing strata of capitalists prevail throughout society and therefore, they must be dealt with at a different sphere of time - as though one who owns more means of production over another exploits humanity any differently?! Did Marx not write that "whether a tree is large or small it is a tree" (Marx, 1977: 213). Marx denounced any premise that made any bourgeoisie, within any country, inferior, subordinate, or different to another bourgeois capitalist regardless of their place of residence. To this, Marx rightly addressed that all bourgeois capitalist were the same in purpose, power, and unification with other capitalists regardless of location:

A certain kind of brotherhood does of course exist among the bourgeois classes of all nations. It is a brotherhood of the oppressors against the oppressed, of the exploiters against the exploited. Just as, despite the competition and conflicts existing between the members of the bourgeoisie, the bourgeois class of one country is united by brotherly ties against the proletariat of that country, so the bourgeois of all countries, despite their mutual conflicts and competition on the world market, are united by brotherly ties against the proletariat of all countries. For the peoples to be able truly to unite, they must have common interests. And in order that their interests may become common, the existing property relations must be done away with, for these property relations involve the exploitation of some nations by others: the abolition of existing property relations is the concern only of the working class. It alone has also the means for doing this. The victory of the proletariat over the bourgeoisie is, at the same time, victory over the national and industrial conflicts which today range the peoples of the various countries against one another in hostility and enmity. And so the victory of the proletariat over the bourgeoisie is at the same time the signal of liberation for all oppressed nations ... Defeat your own internal enemies and you will then be able to pride yourselves on having defeated the entire old system (1976: 388).

This position is also shared by Lenin (1966b: 241-242) who stated that there existed "a certain rapprochement between the bourgeoisie of the exploiting countries and that of the colonies". In this alliance, he went on to state that "very often-perhaps even in most cases-the bourgeoisie of the oppressed countries ... is in full accord with the imperialist bourgeoisie" in the purpose of combating "all revolutionary movements and revolutionary classes". It is surrounding this issue, and the words of Marx and Lenin, that Trotsky fumbled upon his own internationalist theory. Trotsky (2000: 158) stated that a country could defend the besieged 'fatherland" "if we first bind our own capitalists hand and foot and hinder them from attacking" the fatherland. What Trotsky failed to retain is that the capitalists within these countries were not separated but united. Another problem arose when Trotsky (2000: 161) claimed "it will be the duty of the international proletariat to aid the oppressed countries in their war against the oppressors". The problem then unfolding is two-fold: 1) How is the proletariat 
was able to come to, and support, a different thesis than that found in Trotsky's canon of bourgeois-democratic revolution and democratic tasks (Trotsky, 1969).

Lenin diffused both the bourgeois-democratic thesis and those subjective positions that saw the peasantry as an ineffectual character in the revolution process. Lenin demonstrated that in backward countries a large proportion of the population were of peasant origin; persons who had already deeply subscribed to a bourgeois model of capitalist relations. Therefore, within these regions bourgeois-democratic movements were, and had been for some time, realized. In addition, Lenin illustrated the failings of such positions as lacking in their material socio-politically examination of the contextual conditions that vary between nations:

I should like especially to emphasize the question of the bourgeois-democratic movement in backward countries. This is a question that has given rise to certain differences. We have discussed whether it would be right or wrong, in principle and in theory, to state that the Communist International and the Communist parties must support the bourgeois-democratic movement in backward countries. As a result of our discussion, we have arrived at the unanimous decision to speak of the nationalrevolutionary movement rather than the "bourgeois-democratic" movement. It is beyond doubt that any national movement can only be a bourgeois-democratic movement, since the overwhelming mass of the population in the backward countries consist of peasants who represent bourgeois-capitalist relationships. It would be utopian to believe that proletarian parties in these backward countries, if indeed they can emerge in them, can pursue communist tactics and a communist policy, without establishing definite relations with the peasant movement and without giving it effective support (1966b: 241-242)

In a staccato-like manner, Lenin presented how, by 1920, the Soviet Republics of Bokhara, Azerbaijan, and Armenia all demonstrated that nations, as argued throughout the national question and the later works of Marx, had the capacity to not only arise and obtain their own independence but so too could these countries create centralized governments that were firmly 'in the hands of workers and peasants'. In citing these republics, Lenin came to an important point toward the peasantry as well, in some ways similar to Marx's claims made in 1882. Lenin illustrated that nations (of a peasant social basis) did not identically replicate the advanced capitalist countries (industrial proletarians) but rather came to a place of socialist governance albeit a different methodology. Instead of replicating a bourgeois-democratic thesis, these countries were able to begin a socialist society through

within the advanced countries going to assist the oppressed countries, while they themselves are under attack?; and 2) How can the international proletariat defend another oppressed country while it itself is trying to combat its own internal capitalist conditions? Trotsky not only contradicted himself but illustrated the paradox found within his own theory: one cannot seek to assist and defend another without taking care of their own internal class conditions; however, one cannot eliminate their own internal class conditions without the assistance of another. 


\section{The Differing Revolutionary Positions of Gramsci and Trotsky in Relation to Classical Marxism, the Peasantry, and the Majority World}

methods of self-determination within the contextual confines of their specific conditions. It was from these lessons that Lenin clearly illustrated that "not only in the industrially developed countries" can the shift to a socialist dynamic be realized, "but also in those which have the peasantry as their basis" (Lenin, 1966c: 490-491).

\section{Conclusion}

Gramsci openly denounced Trotsky's theory as a contradictory Western and ironically unrealistic account of the realities of global capitalism and its affect on the worlds proletariat via national circumstances. The basis of Gramsci's condescending remarks toward Trotsky were based on the fact that Trotsky, while appearing to be an internationalist supporter of revolutionary strategy, in fact displayed a superficially nationalist interpretation that rejected not only the equality and diversity of proletarians but also their capacity to implement socialist emancipation due to their lack of Western capitalist resemblance (Gramsci, 1971). To this position, Gramsci again reflected Lenin's protest of thinking in a dogmatic, especially Western frame of analysis, failing to comprehend the realities of imperialism and its applications and formations with specific countries. For example, Martin Jay (1984: 163) documented that Trotsky's permanent revolution was, according to Gramsci, greatly "inappropriate as a policy in a country like Italy, where a gradual building of coalitions among oppressed groups was absolutely essential". As noted within the Southern Question,

The proletariat can become the leading and dominant class in the measure in which it succeeds in creating a system of class alliances that will permit it to mobilize the majority of the working population against capitalism and the bourgeois State (Gramsci, 1995: 19).

Unlike Trotsky, Gramsci (1995: 19) acknowledged that the socialist revolution "depends on the measure in which it is successful in obtaining the consensus of the large peasant masses." In the present day, with the vast bulk of the majority world being comprised of peasants, it is imperative that the proletariat consolidate agrarian issues important to the peasantry in "its revolutionary program of transition" 26 to attract the peasantry, for

it is necessary, in order to win the trust and consensus of the peasants and of some semi-proletarian categories within the cities, to overcome certain prejudices and conquer certain forms of egoism which can and do subsist within the working class as such, even when craft particularism has vanished. The metal worker, the carpenter, the builder, etc., must not only think as proletarians and no longer as metal worker, carpenter, builder, etc., but they have to take one more step forward; they have to think like workers who are members of a class that aims to lead peasants and intellectuals. Of a class which can win and build socialism only if it is helped and followed by the large majority of these social strata (Gramsci, 1995: 27).

26 (Gramsci, 1995: 20). See also Lenin (1964d). 
All one need do is reflect upon the important (and successful) anti-systemic struggles of the contemporary period to realize the importance of Gramsci's thesis; be it the Bolivarian Revolution assisting the disposed within Venezuela and abroad, the revolutionary social movements in Colombia resisting imperial expansion, or the many organized, thriving, and succeeding organic struggles throughout much of Latin America. Gramsci's promotion of classical Marxism, national conditions, the importance of the peasantry, and the adoption of non-dogmatic forms of social change acknowledges the consequential capacity of the majority world to respond to imperialism through its domestic understanding and response to capitalism.

Not only did Gramsci's theoretical prowess negate Trotsky's thesis of permanent revolution through its rich illustration of thoroughly examining, understanding, and contextually responding to revolutionary conditions, but it also demonstrated the necessity of alliances with the peasantry (today one of the largest populations on the planet whom greatly exist solely within the majority world). Like Trotsky, Gramsci, as did Lenin, reasoned that a material and cultural-political solidarity would be needed in order to eventually procure a proletarian revolution. Both Trotsky and Gramsci acknowledged the tremendous necessity of consolidating the Communist struggle globally and cited the importance of internationalism throughout their lives (Trotsky, 2000; 1969; Gramsci, 1977; 1971). However, unlike the former, Gramsci (1971: 165) fully disregarded "the theory of socalled permanent revolution" as a dismissal of the proletarian realities facing the workingclass in the vast majority of countries. Emphasizing the capacity and need to address internal conditions, Gramsci understood and acknowledged the potential power of the majority world and the peasantry as a formidable power that would not be subservient to the struggle but an essential equal in its realization. In doing so, he clearly aligned himself within a Marxist-Leninist theoretical posture where Lenin himself affirmed that "in this age of imperialism, it is particularly important for the proletariat and the Communist International to establish the concrete economic facts and to proceed from concrete realities, not from abstract postulates, in all colonial and national problems" (1966b: 240). ${ }^{27}$ In his foresight and understanding of the revolutionary capacity of all peoples, Gramsci's work depicted a more realistic consequential model from which the national and international anti-capitalist struggles of today can focus. 


\section{REFERENCES}

Amin, S. 2004. The Liberal Virus: Permanent War and the Americanization of the world. New York, NY: Monthly Review Press.

Consolo, M. 2004. Interview with Marco Consolo, Department Head of International Development for the Partito della Rifondazione Comunista (PRC) in Bogotá, Colombia (December 4).

Fiori, G. 1971. Antonio Gramsci: Life of a Revolutionary (translated by Tom Nairn). New York, NY: New Left Books.

Gramsci, A. 2000a. The Antonio Gramsci Reader: Selected Writings, 1916-1935 (Edited by David Forgacs and introduction by Eric Hobsbawm). New York, NY: New York University Press.

Gramsci, A. 2000b. The Modern Prince \& Other Writings. New York, NY: International Publishers.

Gramsci, A. 1995. The Southern Question (Translation and Introduction by Pasquale Verdicchio). West Lafayette, IN: Bordighera.

Gramsci. A. 1994. Pre-Prison Writings (Edited by Richard Bellamy, Translated by Virginia Cox). Cambridge, UK: Cambridge University Press.

Gramsci, A. 1978. Selections from Political Writings (1921-1926) (Edited and Translated by Quintin Hoare). New York, NY: International Publishers.

Gramsci, A. 1977. Selections from Political Writings (1910-1920) (Edited by Quintin Hoare, Translated by John Mathews). New York, NY: International Publishers.

Gramsci, A. 1971. Selections from the Prison Notebooks of Antonio Gramsci (Edited and Translated by Quintin Hoare and Geoffrey Nowell-Smith). New York, NY: International Publishers.

Gramsci, A. 1957. The Open Marxism of Antonio Gramsci (Translated and Annotated by Carl Mazani). New York, NY: Cameron Associates.

Jay, M. 1984. Marxism \& Totality: The Adventures of a Concept from Lukács to Habermas. Berkeley, CA: University of California Press. 
Le Blanc, P. 1996. From Marx to Gramsci: A Reader in Revolutionary Marxist Politics (Historical Overview and Selection by Paul Le Blanc). Atlantic Highlands, NJ: Humanities Press International.

Lenin, V.I. 1968. Collected Works Volume 39: Notebooks on Imperialism. Moscow, USSR: Progress Publishers.

Lenin, V.I. 1966a. "On the Slogan for a United States of Europe" in Collected Works Volume 21: August 1914 - December 1915. Moscow, USSR: Progress Publishers, pp. 229-343.

Lenin, V.I. 1966b. "Report of the Commission on the National and the Colonial Questions July 26" in Collected Works Volume 31: April-December 1920 Moscow, USSR: Progress Publishers, pp. 240-245.

Lenin, V.I. 1966c. "The Eighth All-Russia Congress of Soviets" in Collected Works Volume 31: April-December 1920. Moscow, USSR: Progress Publishers, pp. 461-534.

Lenin, V.I. 1965a. "One Step Forward, Two Steps Back (The Crisis in Our Party)" in Collected Works Volume 7: September 1903 - December 1904. Moscow, USSR: Progress Publishers, pp. 203-425.

Lenin, V.I. 1965b. "Two Tactics of Social-Democracy in the Democratic Revolution" in Collected Works Volume 9: June - November 1905. Moscow, USSR: Progress Publishers, pp. 15-140.

Lenin, V.I. 1965c. "Concluding Paragraph to the article 'The Paris Commune and the Tasks of the Democratic Dictatorship"' in Collected Works Volume 9: June November 1905. Moscow, USSR: Progress Publishers, pp. 141.

Lenin, V.I. 1965d. "Guerrilla Warfare” in Collected Work Volume 11: June 1906 January 1907. Moscow, USSR: Progress Publishers, pp. 213-223.

Lenin, V.I. 1964a. “Capitalism in Agriculture (Kautsky's Book and Mr. Bulgakov's Article)" in Collected Works Volume 4: 1898-April 1901. Moscow, USSR: Progress Publishers, pp. 105-159.

Lenin, V.I. 1964b. "What Is to Be Done? Burning Questions in the Movement" in Collected Works Volume 5: May 1901 - February 1902. Moscow, USSR: Progress Publishers, pp. 347-529. 
Lenin, V.I. 1964c. "Draft Programme of the Russian Social-Democratic Labour Party" in Collected Works Volume 6: January 1902-August 1903. Moscow, USSR: Progress Publishers, pp. 27-33.

Lenin, V.I. 1964d. "To the Rural Poor: An Explanation for the Peasants of what the Social-Democrats Want" in Collected Works Volume 6: July 1902 - August 1903. Moscow, USSR: Progress Publishers, pp. 361-432.

Lenin, V.I. 1964e. "Imperialism, The Highest Stage of Capitalism: A Popular Outline" in Collected Works Volume 22: December 1915 - July 1916. Moscow, USSR: Progress Publishers, pp. 185-304.

Lenin, V.I. 1964f. "Letters on Tactics" in Collected Works Volume 24: April-June 1917. Moscow, USSR: Progress Publishers, pp. 42-54.

Löwy, M. 2005. The Theory of Revolution in the Young Marx. Chicago, IL: Haymarket Books.

Marx, K. 1996a. "Preface to the First German Edition" in Collected Works Volume 35: Capital, Vol. 1. New York, NY: International Publishers, pp. 7-11.

Marx, K. 1996b. "Capital: A Critical Analysis of Capitalist Production" in Collected Works Volume 35: Capital, Vol. 1. New York, NY: International Publishers, pp. 31-761.

Marx, K. 1992. "Marx to Vera Zasulich" in Collected Works Volume 46: 1880-1883. New York, NY: International Publishers, pp. 71-72.

Marx, K. 1989a. "Letter to Otechestvenniye Zapiski" in Collected Works Volume 24: 1874-1883. New York, NY: International Publishers, pp. 196-201.

Marx, K. 1989b. "Drafts of the Letter to Vera Zasulich" in Collected Works Volume 24: 1874-1883. New York, NY: International Publishers, pp. 346-369.

Marx, K. 1989c. "Letter to Vera Zasulich" in Collected Works Volume 24: 1874-1883. New York, NY: International Publishers, pp. 370-371.

Marx, K. 1989d. "Notes on Bakunin's Book Statehood and Anarchy" in Collected Works Volume 24: 1874-1883. New York, NY: International Publishers, pp. 485-526. 
Marx, K. 1988. "On the Hague Congress" in Collected Works Volume 23: 1871-1874. New York, NY: International Publishers, pp. 254-256.

Marx, K. 1987. "Preface to A Contribution to the Critique of Political Economy" in Collected Works Volume 29: 1857-1861. New York, NY: International Publishers, pp. 261-265.

Marx, K. 1985. "Inaugural Address of the Working Men's International Association" in Collected Works Volume 20: 1864-1868. New York, NY: International Publishers, pp. 5-13.

Marx, K. 1983. "Marx to Engels in Manchester" in Collected Works Volume 40: 1856-1859. New York, NY: International Publishers, pp. 345-347.

Marx, K. 1978. "The Class Struggle in France" in Collected Works Volume 10: 1849-1851. New York, NY: International Publishers, pp. 45-145.

Marx, K. 1977. "Wage Labour and Capital” in Collected Works Volume 9: 1849. New York, NY: International Publishers, pp. 197-228.

Marx, K. 1976. "Marx's Speech: Speeches at the International Meeting held in London on November 29, 1847 to mark the 17th anniversary of the Polish Uprising of 1830" in Collected Works Volume 6: 1845-1848. New York, NY: International Publishers, pp. 388-389.

Marx, K. and F. Engels 1998. "Capital: A Critique of Political Economy Volume III” in Collected Works Volume 37: Capital Vol. III. New York, NY: International Publishers, pp. 27-897.

Marx, K. and F. Engels 1989. "Preface to the Second Russian Edition of the Manifesto of the Communist Party" in Collected Works Volume 24: 1874-1883. New York, NY: International Publishers, pp. 425-426.

Marx, K. and F. Engel 1977. "The Defeat of the Piedmontese" in Collected Works Volume 9: 1849. New York, NY: International Publishers, pp. 169-177.

Marx, K. and F. Engels 1976. "Manifesto of the Communist Party" in Collected Works Volume 6: 1845-1848. New York, NY: International Publishers, pp. 476-519. 
Munck, Ronaldo (1984) Politics and Dependency in the Third World: The Case of Latin America. London, UK: Zed Books.

Rochester, A. 1942. Lenin on the Agrarian Question. New York, NY: International Publishers.

Sacouman, R. J. 1999. Social Theory for a Change: Vital issues in the Classics. Toronto, ON: Irwin Publishing.

Spriano, P. 1979. Antonio Gramsci and the Party: The Prison Years (translated by John Fraser). London, UK: Lawerence and Wishart.

Trapeznikov, S. P. 1981. Leninism and the Agrarian and Peasant Question Volume 1:

Lenin's Agrarian Programmes and the Three Russian Revolutions. Moscow, USSR: Progress Publishers.

Trotsky, L. 2000. The Transitional Program for Socialist Revolution (with Introductory Essays by Joseph Hansen and George Novack). New York, NY: Pathfinder Press.

Trotsky, L. 1969. The Permanent Revolution and Results and Prospects. New York, NY: Merit Publishers.

Trotsky, L. 1936. The History of the Russian Revolution: Volume 1. New York, NY: Simon and Schuster. 